\title{
Investigating Factors that affecting the Continued use of Internet Banking: Case Study of Libya
}

\author{
${ }^{*}$ Ali Rfieda, Mira Kartiwi \\ International Islamic University Malaysia, Malaysia \\ *ali.rafieda@live.iium.edu.my
}

\begin{abstract}
After technological progress and in particular the development of internet, internet banking service has intensified the competition between banks as well as allowed customers to easily compare the services that provided by different banks. While the goal of any business entity in the long term is to increase its productivity and maximisation of the profits, customer retention becomes an important component of banking strategy in today's increasingly competitive environment to foster customer relationship management. In order to achieve this, it is important to concentrate on the consumer's continued use of a service rather than solely on their acceptance of the service (Adapa, 2011). Therefore, understanding the importance of consumers' continued use is the key element to maximise customers' retention in internet banking services.
\end{abstract}

Keywords: Internet banking, continued use, customers' retention, distributional view, cognitive view, relational view

\section{Introduction}

After technological progress and in particular the development of internet that occurred in the world, many helpful online services and applications such as internet banking is no longer an elusive dream. Over the past few years since 1990, advancement in information and communication technology has revolutionized the way financial services operate and conduct their business. The internet provided much of the force on this front. The internet not only made banks provide their services online, but also reduce operation costs, increase revenues and sales, improve the quality of service and offer new ways of doing business, as well as gain competitive advantage over their rivals. Internet-banking is a technology that gains enormous adoption across many countries. However, according to (Schlich, 2012), the biggest concern for internet banking today is not only acquiring new customers but retaining them. In addition, it is only recently that researchers have started to understand the importance of consumers' continued use of internet banking (Adapa, 2011). Customers' deal with internet banking can be understood in three different stages: Pre-adoption, adoption, and post-adoption. In addition, at the pre-adoption stage, customers may examine internet-banking service and consider adopting it. At the adoption stage, they form an intention to adopt the service, and they eventually use it. At the post-adoption stage, customers can either continue to use the service or abandon it (Kim \& Crowston, 2011). Studies show that continued use is important due to the fact that continued use is important because retaining actual clients is cheaper than acquiring new ones. Also, continued use is important due to that an eventual website success depends on its continued use after initial use or acceptance (Elmezni \& Gharbi, 2010).However, there are limited empirical studies that attempt to investigate the factors that influence consumers' continued use of internet banking. Among these previous studies, little attention has been given to the developing countries, where the development of e-banking is still on early stage. Thus, this study aims to sheds the light on the factors that may influence the continued use of internet banking in Libya. The proposed conceptual framework will incorporate the constructs of distributional view, cognitive view and relational view.

Problems Statement: Despite the importance of continued use, most studies of internet banking in the literature focused on customers' adoption or acceptance rather than continued use. In addition, this area of study is important because it has been neglected (Adapa, 2011; Eriksson \& Nilsson, 2007; Ho \& Ko, 2008; Sheng \& Lu, 2009; Yoon \& Barker Steege, 2012). According to (Bhattacherjee, 2001 b), the initial acceptance of a technology is an important first step; however, the eventual success of the technology depends on its continued use. Moreover, despite the rapid increase of internet users and cited benefits of using internet banking, the number of internet banking users has not risen as strongly as expected by the scholars and banks(Yoon \& Barker Steege, 2012). In addition, customers still have anxiety and doubt about whether they want to continue using internet banking even after they try it (Ho \& Ko, 2008). 
According to Cho's (2005), factors from technological, system, and application domains, as well as individual characteristics, should all be taken into account in order to yield an overall picture of technology adoption and usage (Cho, Cheng, \& Hung, 2009). Nonetheless, the significant role of cognitive view on continued use has been neglected in the previous studies and it is limited to the study of (Cho, et al., 2009). In addition, most of previous studies conducted from three different perspectives which are transactional view, relational view and some has mixed transactional view, relational view (Li \& Chau, 2009). In addition, in the studies with the integrated or mixed view, researchers often integrate one or two most widely investigated factor from one view into a well-established theoretical framework such as TAM (Li \& Chau, 2009). To our knowledge, there are few empirical studies that attempt to investigate the factors that influence consumers' continued of internet banking. In addition, among these previous studies, however, little attention has been given to the developing countries, where the development of internet banking is still on early stage. Furthermore, none of previous studies has been done in Libya with regard to continued use of internet banking service; also this is the first study that combines distributional view, cognitive view and relational view in order to get more explanation to understand the key influential factors that affecting continued use of internet banking.

Research questions: The current study will be focusing on identifying the various factors that may influence customers' continued use of internet banking services in Libya. As such, the following research questions are considered worthy of investigation:

- What are the factors that affecting continued use of internet banking?

- What are the relationships between the proposed factors? In addition, how do these relationships affect continued use of internet banking?

- Does self-efficacy moderate the relationships amongst reputation, customer satisfaction, switching costs and perceived usefulness in order to gain customer retention?

\section{Literature review}

Internet banking in Libya: Wenchao \& Jordan (2009) stated that internet banking is a technology that gains enormous adoption across many countries such as the United States and India, and the rate of adoption internet banking varies among countries. In addition, the adoption rate of internet banking is still quite low in many other counties, such as Libya. Over the past two decades, the banking industry in Libya has experienced very significant development by using computerized systems. For instance, according to (LCBD annual report 2009), Bank of Commerce and Development in Libya (LBCD) is the first Libyan bank begun to offer internet banking services to its customers in 2007. However, according to (LCBD annual report 2009)only 1.33\% of the total customers of Bank of Commerce and Development in Libya (LBCD)have online banking account in 2009. Instead, customers continue getting their banking services using traditional banking channels through bank's branches (Twati, 2008). Amongst the Arab countries, Libya has a reputation for having "the finest bankers but the worst banks" (Abukhzam \& Lee, 2010). The Libyan banking industry is under increased pressure to improve its banking services. In addition, the increasing demand from the international banking community and the public are placing significant pressure on Libyan banks to be electronically ready (Abukhzam \& Lee, 2010). Also, the large distance between Libyan banks has also created a pressure for connecting the headquarters with their branches electronically, rather than handling cash and paper manually ("CBL annual report," 2007). Recently, to keep up with the rest of the world, the Libyan banking system is currently undergoing a substantial modernization program to upgrade available services, establish a functioning national payments system, facilitate the use of non-cash payment instruments and institute new standards of accounting and training (Twati, 2008).

Internet banking continued use: Internet banking is a technology that allows customers to do many online banking operations 24 hours/ day without leaving home or business in a complete virtual environment (Hashim \& Chaker, 2008). Internet banking defines as an information system that offers to the customers the opportunity to conduct their financial transactions on the internet (Zahid, Mujtaba, \& Riaz, 2010). Similarly, internet banking also defines as an internet portal, through which consumers can use different kind of banking services ranging from bill payment to making investment(Pikkarainen, Pikkarainen, Karjaluoto, \& Pahnila, 2004).Furthermore, with the exception of cash withdrawals, internet banking offers to customers the ability to conduct almost any other type of banking transactions. While customer movement from traditional banking to internet banking requires new sets of strategies to attract customers and retain existing ones became more critical (Karjaluoto, Mattila, \& Pento, 2002), there has been an extensive research in internet banking domain. However many of the earlier studies in 
internet banking context focused on customers' adoption or acceptance rather than continued use. Due to the continued calls from some scholars, the attention had shifted from attracting customers to the online services to retaining them. Furthermore, recent research also highlighted that the initial acceptance of internet banking is an important indicator of its success, but it does not necessarily lead to the desired outcomes unless the use continues (Bhattacherjee, 2001a). Hence, for banks to gain the desired advantages and profits of internet banking technology, understanding the factors that impact on continued use of internet banking becomes more critical. Internet banking continued use can be defined as continued usage of internet banking services by adopters, where a continuance decision follows an initial acceptance decision (Lee \& Kwon, 2009). Recently, there have been frequent calls from number of scholars such as (Elmezni \& Gharbi, 2010; Ernovianti, Kamariah Nik Mat, Kassim, Rashid, \& Syaheera Meor Shaari, 2012; Schlich, 2012)for more understanding the customers' continued use of internet banking. As a response for these calls, this study assumes that effective strategies of internet banking continued use is regarded as a vitally important issue in the banking industry.

Expectation-Confirmation Model of continued IT usage (ECM-IT): In one of the earliest works on information technology (IT) continued use behaviour, Bhattacherjee (2001b) developed and empirically tested Expectation-Confirmation Model of continued IT usage (ECM-IT) by taking into account the distinctions between acceptance and continuance behaviours. ECM-IT is rooted in the expectation disconfirmation theory (EDT) which developed by Oliver in1980 and widely used in the marketing field. (Bhattacherjee, 2001 b; Li \& Chau, 2009; Thong, Hong, \& Tam, 2006). Drawing on EDT, Bhattacherjee (2001a, 2008) stated that the process of customers' continued use intention in information system field has some features that are similar to continued use intention in marketing field. (Bhattacherjee, 2001a)focused on transactional view which views a web site as an information technology. Thus, he treated perceived usefulness (PU) from the technology acceptance model (TAM) and satisfaction from expectation diffusion theory (EDT) as the predictors of continued use to explain customer's intention of online services continued use (Li, et al., 2006). In addition, ECM-IT suggests that users' intention to continue using a technology is driven by their satisfaction with prior usage of that technology and their perceived usefulness of further usage (Bhattacherjee, 2001b).

Despite that ECM_IT structured from the expectation confirmation theory and TAM, it has some unique characteristics. Firstly, the ECM-IT focuses on the post-adoption expectations, rather than pre-adoption expectations because continuance behaviour may be different from initial acceptance and temporary use (Bhattacherjee, 2001a). Secondly, in ECM-IT, expectation variable of ECT is represented by perceived usefulness (PU) is based on the justification that perceived usefulness is a cognitive belief salient to information system use(Davis, 1989). Thirdly, perceived performance is not included in the ECM-IT, as it assumes that the effect of perceived performance is already interpreted by the confirmation construct (Min \& Shenghua, 2007). ECM-IT has some unique features where it highlights the importance of post adoption expectations rather than pre-adoption expectations. ECM-IT is a newly developed model, which requires empirical validations across different technology contexts to determine its generalizability. In addition to its empirical validation, a comparison with other models can reveal its relative utility for understanding the continued IT usage behaviour (Thong, et al., 2006).

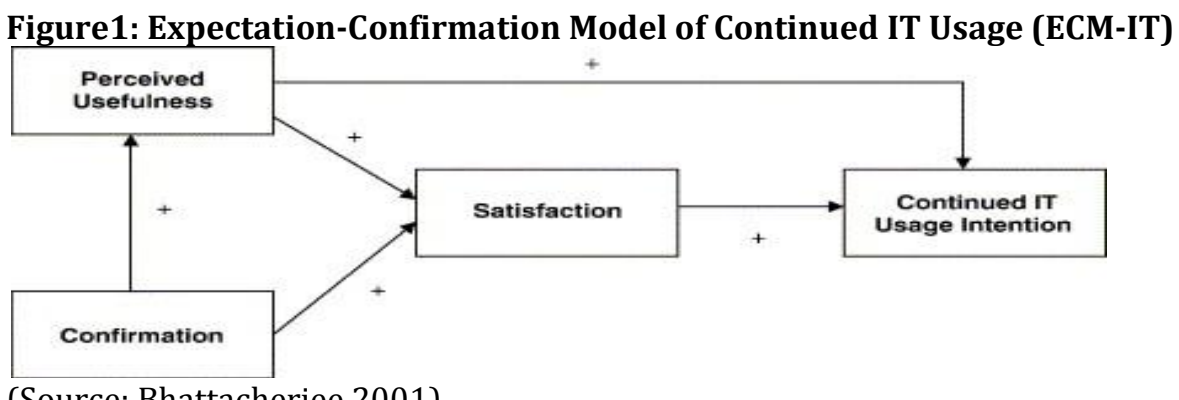

(Source: Bhattacherjee 2001)

Commitment Trust Theory (CTT): Previous studies stress the critical important role of trust and commitment in building successful long-term relationships in the online services context(Mukherjee \& Nath, 2007; Vatanasombut, Igbaria, Stylianou, \& Rodgers, 2008). One of the models that examine trust and commitment in online services is the Commitment-Trust Theory(CTT), which was developed by Morgan and Hunt (1994). CCT Is a theory predicts that a strong long-term relationship between eservices' providers and customers is the main reason for the customers' continued use of the system. 
Commitment-trust theory was originally developed in the B2B context. However, it has been successfully applied within the context of B2C too (Chen, 2004; Eastlick, Lotz, \& Warrington, 2006; Mukherjee \& Nath, 2007). Unlike the transactional view of ECM-IT, the relational view of CCT suggests that satisfaction does not always guarantee continued use and that satisfaction is a necessary but not sufficient factor for customer retention (Jones \& Earl Sasser, 1995; Riquelme, Mekkaoui, \& Rios, 2009; Singh, 2006). Instead, continued use is perceived as a result one of the customer's commitment to and trust in the relationship with the e-services' suppliers (Riquelme, et al., 2009).

In recent review of a number of models on relational exchange domain, CTT was found to be the only model that explicitly includes a construct which similar to customer retention as an outcome of the model. In commitment-trust theory (CCT), trust and commitment are viewed as key mediating variables (KMV) between antecedents and outcomes of the relationship between customers and e-services' providers (Morgan \& Hunt, 1994) as shown in Figure 2. In addition, relationship commitment and trust found to be strong predictors of continuance intention (Vatanasombut, Igbaria, Stylianou, \& Rodgers, 2008). Among the several outcomes of CTT, propensity to leave a relationship is relevant to the current study of internet banking continued use. According to (Morgan and Hunt, 1994), propensity to leave described as the likelihood that a partner terminates a business relationship in the near future and thus appears as continued use (Li \&Chau, 2009). In addition, switching cost, which is one of the antecedent factors of commitment and trust, has also adopted in this study. Moreover, according to (Wong, 2011), Sheshunoff (2000) stated that the single most important factor for full service internet banks is the need to create powerful switching cost. While the focus of this study is on the factors that influence continued use of internet banking, so that this study does not consider other outcomes and antecedent factors of commitment and trust because low significant effect on / or not related to continued use.

Figure2: CTT (Morgan \& Hunt, 1994)

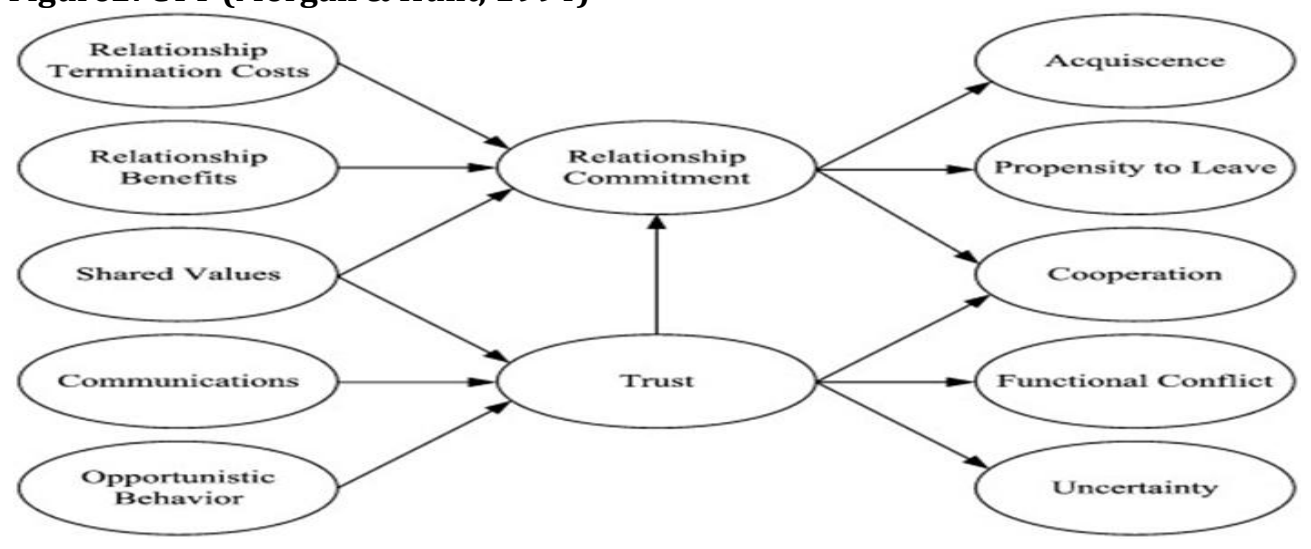

Social cognitive theory (SCT): During the past decade, studies in the information system literature have demonstrated the importance of cognitive forces for predicting and improving computer and internet usage behaviours (Lin \& Huang, 2008). The social cognitive theory is the theory that deals with cognitive, emotional and of behavioural aspects to explain, customers' cognitive revaluations after their initial use (Cohen \& Goldberg, 1970). Many researchers argue that individuals would seek cognitive re-evaluations after their initial usage (Cohen \& Goldberg, 1970; Huei-Huang, Gee-Woo, \& Jumin, 2007; Santos \& Boote, 2003). The Social Cognitive Theory (SCT) stemmed from the Social Learning Theory (SLT), which has a rich historical background dating back to the late 1800's, and expanded upon and theorized by Albert Bandura from 1962 until the present. Social cognitive theory (SCT) has three dimensions as shown in Figure 3. In addition, SCT explains that how a person's functions is determined by the interaction of personal factors, such as, self-efficacy, behaviour factors such as recommendation and environmental factors such as reputation. Moreover, (Bandura, 2008, 2009; Bandura \& Locke, 2003) argued that selfefficacy that represents personal dimension is a major cognitive force guiding people's behaviour. Social cognitive theory (SCT) is a widely accepted, empirically validated model of individual behaviour. In addition, SCT argues that a person's cognitive behaviour is partially shaped and controlled by the influences of social network and the person's cognition (Lin \& Huang, 2008). Therefore, this study assumes that self-efficacy, recommendation and bank's reputation are the cognitive factors that influence customers in the context of internet banking continued use. 
Figure3: The three major dimensions of SCT. Adapted from Bandura, 1986, p. 263)

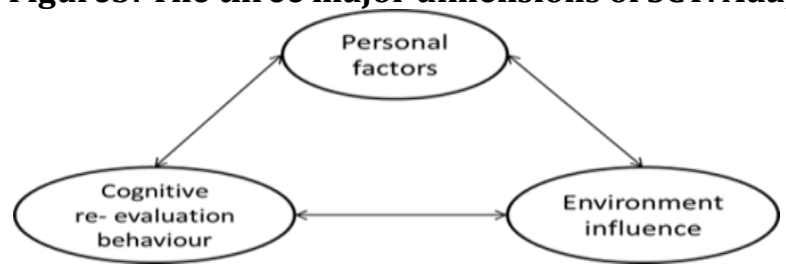

Research model and hypotheses: The aim of this study is to determine the factors that may influence the continued use of internet banking. Hence, this study proposes a framework based on an extensive review of current literature in related areas of internet banking and continued use domains. In this study, three model/ theory related to the concept of transactional, relational and cognitive views will be adopted namely Expectation-Confirmation Model of continued IT usage (ECM-IT), Commitment Trust Theory (CTT) and Social Cognitive Theory (SCT). The framework for this research (see Figure 4) extends ECT-IT by integrating with CTT and SCT. While Most of previous studies have described and studied adoption, acceptance, and use of online services from the transactional view, others have emerged the relational view (Li \& Chau, 2009) and cognitive view (Cho, Cheng, \& Hung, 2009)in the theory of information system research and e-business practices. In addition, transactional view considers the interaction between a customer and e-service provider as a business transaction occurring at the interface of website (Gefen, Karahanna, \& Straub, 2003). The transactional view emphasizes satisfaction and usefulness and focused on the economic benefits for both the customer and the online business, with an aim at improving business transactions through efficient and effective website design. On the other hand, the relational view of online customer relationships focuses on the social and psychological factors and humanistic aspects of the interactions, such as trust and loyalty (Li \& Chau, 2009).

In contrast, the cognitive view explains how people acquire and maintain certain behavioural patterns depending on a specific knowledge or ability they have (Bandura, 1991; Hsu, Chiu, \& Ju, 2004). In addition, (Cho, et al., 2009) stated that cognitive view concerned with the degree to which relevant cognitive elements are compatible. Cognitive elements include knowledge, attitudes, and beliefs about the self, as well as the environment. In addition, this study assumes that SCT explains how a person's functions is determined by the interaction of personal factors, such as, self-efficacy, behaviour factors such as recommendation and environmental factors such as reputation. In accordance with previous studies, this study aims to adopt mixed viewpoint of the transactional view to cover environmental factors and the relational view to cover human behaviour as well as cognitive factors have been combined. Moreover, this study argues that ECM_IT (Bhattacherjee, Perols, \& Sanford, 2008) focused on the transactional view and CTT (Morgan and Hunt 1994) has the essence of the relational view. In addition, the study assumes that SCT covers the cognitive factors. Therefore, we combine Expectationconfirmation Model of continued IT usage (ECM-IT) with Commitment-Trust theory (CTT) and Social Cognitive Theory (SCT) to express the cognitive issue.

There are two motives that explain why the ECT-IT, SCT and CTT models/ theories were chosen in this study. First, an assessment of previous studies shows that both ECT-IT and CTT had widely been used to assess the concept of continued use in IT domain. In addition, SCT recently also found to has an important role for assessing continued use of IT(Cho, et al., 2009). Second, the limited or absence of study on continued use in literature review that had adopted the mixed views of transactional, cognitive and relational constructs in one conceptual framework (Cho, et al., 2009; Li \& Chau, 2009). Building on this, our research develops a model and represents a careful and systematic effort to incorporate factors from various distinct theories (ECM-IT, SCT and CTT). An overview of the research model proposed is shown in Figure 4. This study proposes a modified model to explain variables that convey continued usage of internet banking in Libya. In addition it is hypothesized that commitment, trust and recommendation mediated the relationship between four precursors (switching cost, reputation, satisfaction and perceived usefulness) and customers' continued use of internet banking. Moreover, despite prior studies have discussed the importance of self-efficacy, little empirical work has been adopted self-efficacy as a moderator factor between commitment and continued use of internet banking services. Therefore, this study assumes that self-efficacy is moderating the relationship between commitment and the continued use of e-banking. 
Figure4: The proposed model

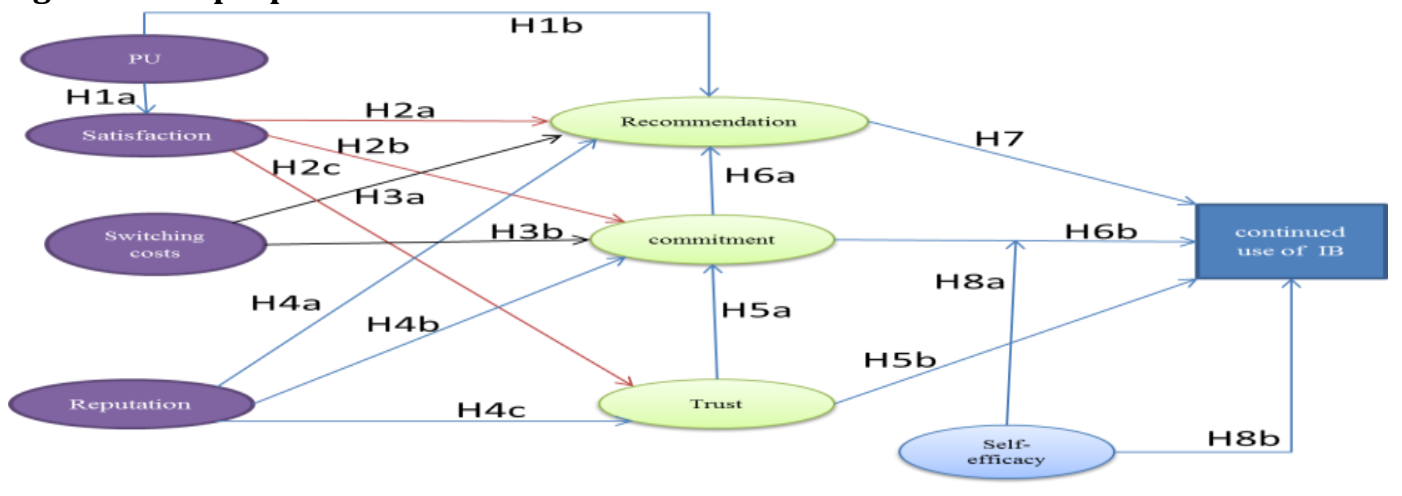

Perceived usefulness (PU): In the expectancy-confirmation paradigm, PU is commonly defined as individual beliefs or sum of beliefs about the levels of attributes possessed by a product/service. According to (Barnes \& Vidgen, 2000), web site is useful if it delivers the services that customer expected, but not if the customers' delivery expectations are not met. Bhattacherjee (2001a) found that users' satisfaction with IT is determined by its perceived usefulness from prior IS use. The ECM posits that users' perceived usefulness of IT has a positive effect on their satisfaction with it. Hence, we assume that users' perceived usefulness of internet banking has positive influences on their satisfaction with the internet banking use. In addition, perceived usefulness could make people more likely to use and recommend it to their peers. Thus, perceived usefulness acts as a persuasive tool that increases social influences on customers' intention towards continued use (Wentzel, Wentzel, Sundar, \& SarmaYadavalli, 2011). Thus, the hypothesis will be formulated as follows:

H1a: Users' perceived usefulness of internet banking use would have a positive effect on their satisfaction with the internet banking.

H1b: Users' perceived usefulness of internet banking use would have a positive effect on their recommendation.

Satisfaction: Satisfaction defined as the summary psychological state resulting when the emotion surrounding disconfirmed expectations is coupled with the consumer's prior feelings about the consumption experience (Oliver \& Linda, 1981). We conceptualize satisfaction as transactional construct, which is built through experiences of a service's usage overtime (J. Kim, Jin, \& Swinney, 2009). In addition, customers with higher levels of satisfaction tend to have higher usage of the service, possess stronger continued use intention, and able to recommend the service to their acquaintances than customers with lower levels of satisfaction(Bolton \& Lemon, 1999). In addition, the relationship between satisfaction and commitment has been found to be significant in numerous studies (J. Kim, et al., 2009). Moreover, Morgan and Hunt (1994) assert that the target of the firms is to develop customer trust beyond customer satisfaction to retain their customers in a long term period. In other word, it has been found that customer satisfaction has a positive effect on customer trust(Nasrin Danesh, Ahmadi Nasab, \& Choon Ling, 2012). Thus, the hypothesis will be formulated as follows:

H2a: satisfaction in internet banking has appositive effect on recommendation.

H2b: satisfaction in internet banking has appositive effect on commitment.

H2c: satisfaction in internet banking has appositive effect on trust.

Switching cost: In this study, switching cost is conceptualized as the perception of the magnitude of additional costs (comprise psychological and emotional costs) required for internet banking customers to terminate the current relationship with their main internet bank and switch to an alternative. Switching costs play an important role in customer retention. Customers who perceive a high level of switching costs may behave differently from those who only perceive a low level of switching costs. In addition, when switching costs are perceived to be high, customers are reluctant to switch to a competing service provider, whereas when the costs of switching are perceived to be low, customers are more likely to switch to a different provider (Colgate \& Lang, 2001). Switching costs has been identified as a factor contributing to maintaining a relationship (Morgan and Hunt, 1994). Moreover, Morgan and Hunt (1994) state switching costs to be of an economic nature only. However, switching costs may comprise of psychological and emotional costs. A number of studies reveal significant positive effects of switching costs on commitment (Aydin \& Özer, 2005; Yang \& Peterson, 2004). Additionally, positive relationship was found between switching costs and recommendation (Konuk \& Konuk, 2013). As a result, when 
banking customers perceive high level of switching costs their willingness to be loyal and recommend their current internet banking providers can be increased. Thus, the hypothesis will be formulated as follows:

H3a: Switching costs have a positive effect on recommendation intentions.

H3b: Switching costs have a positive effect on commitment.

Reputation: Reputation defined as consistency over time of an attribute of an organization such as reputation in term of price, product quality, innovativeness, or global reputation (Yee \& Faziharudean, 2010). According to (Casaló, Flavián, \& Guinalíu, 2008), reputation must be understood as referring not only to the website, but also the entire organization. In the study conducted by Casalo et al. (2008), a more favourable website reputation led to a greater degree of loyalty. Also, favourable interpretations of the online reputation of an online supplier are directly and positively associated with the behavioural intentions of consumers such as loyalty (Goode \& Harris, 2007). Moreover, banks' negative reputation can be negatively correlated with customer trust(Maroofi \& Nazaripour, 2012). It was suggested that perceive reputation is a significant factor to create consumers' trust in an online stores particularly for companies which wish not to be large in their fields (Jarvenpaa, Tractinsky, \& Vitale, 2000). Additionally, a high reputation increases the likelihood that consumers will provide a recommendation(Rogerson, 1983). As a consequence, the hypothesis will be formulated as follows:

H4a: A bank's reputation positively affects customers' recommendation intentions to use internet banking.

H4b: A bank's reputation positively affects customers' commitment to use internet banking.

H4c: A bank's reputation positively affects customers' trust to use internet banking.

Trust: Trust is associated with a set of beliefs and often refers to the role of security and privacy aspects in online environment. While trust has been widely investigated in the context of online services adoption, little attention has been given to it in the context of internet banking continued use. in addition, Among the predictors of the intention to use Internet banking, trust has been found to be one of the most important factors that influence an individual to use the technology (Nor \& Pearson, 2007). Moreover, observed trust had direct and positive impacts on the loyalty commitment of customers, since customer satisfaction itself alone cannot ensure long term commitment of the customer to any service provider (Chiou, 2004; Nasrin Danesh, et al., 2012). In web-based electronic commerce, customers must first trust the business before they commit to it, since maintaining a relationship with the company involves potential vulnerability (Vatanasombut, et al., 2008). In other word, that higher level of trust is significantly associated with a greater willingness to try Internet banking(Vatanasombut, et al., 2008). Li et al. (2006) found that an individual user's continuous usage of an online website was determined by both commitment and trust. Thus, the hypothesis will be formulated as follows:

H5a: Customer trust has a direct positive effect on customer commitment to continued use internet banking.

H5b: Customer trust has a positive effect on customer continued use internet banking.

Commitment: Commitment defined as the customer's durable intention to develop and sustain the relationship with the supplier in the long term (Ryssel, Ritter, \& Gemünden, 2004). In addition, commitment is a factor that widely emerged in previous studies and found to be a significant predictor of continued use. Li et al. (2006) found that an individual user's continuous usage of an online website was determined by both commitment and trust. In addition, (Seyed Ghorban \& Tahernejad, 2012)proved that commitment affects customers' recommendation in a very significant positive manner. In other word, committed customers are the promoters of companies by employing word-of-mouth in positive way and recommend the service to others to help company to increase their customers. Thus, the hypothesis will be formulated as follows:

H6a: Customers who are committed to their relationship with their internet banking providers are likely to recommend the service to others.

H6b: Customers who are committed to their relationship with their internet banking providers are likely to continue using the services offered by that bank.

Recommendation: Recommendation defined as an informal advises that are being transferred among customers(East, Hammond, \& Lomax, 2008). In addition, recommendation is an activity that contains sharing thoughts about a commercially-based experience(Mikkelsen, 2002). Moreover, uncommitted customers can expand their notions by using recommendation in a negative manner, and most of them 
never back to company for repurchasing (Seyed Ghorban \& Tahernejad, 2012). Based on what we discussed here, the hypothesis is formed as follows:

H7: There is a significant relationship between positive recommendation and internet banking continued use.

Self-efficacy: It is refers to an individual's' belief in his/her capability to perform a specific task. Prior studies provided significant support for the role of self-efficacy in the term of online services usage and adoption. In internet banking adoption context, self-efficacy found to have a significant effect on perceived ease of use (Wang, Wang, Lin, \& Tang, 2003). This means that the more high level of selfefficacy customers are the more they perceived internet banking is easy to use. In addition, intention to use internet banking among Malaysian customers is predicted by self-efficiency(Ernovianti, et al., 2012). Additionally, even long after consumers' adoption of internet banking, self-efficacy was found to significantly influence consumers' continued use of internet banking (Adapa, 2011). In addition, it was found that individuals' prior experiences and their past interaction with systems can form their selfefficacy and their confidence to use advanced technology. We used a moderation perspective to illustrate that if individuals are performing a particular behaviour based on their level of self-efficacy, then the predictive power of commitment is weakened. In other word, we expected self-efficacy to have a moderating impact on the relationship between commitment and continued use of internet banking. Thus, the hypothesis will be formulated as follows:

H8a: For a given level of customer commitment, the higher the level of self-efficacy is, the higher is the level of customer continued use internet banking.

H8b: The higher the level of customers' self-efficacy leads to the higher level of continued use of internet banking.

\section{Methodology}

Questionnaire development: A questionnaire will be developed to measure consumer intention to continue using of online services banking offered by the banks in Libya. The questionnaire initially will include 57 items divided between 9 constructs as described below. Most of the items that adopted have been already successfully used in other literatures. Out of the collected items, some items were eliminated since they are conceptually far from continued use context. For each item of 14 constructs, seven-point Likert scales were utilized and were anchored by $1=$ strongly disagree and $7=$ strongly agree with $3=$ neutral (neither agree nor disagree) as the midpoint. It is worth to indicate that the questionnaire will be written in English language, and then it will be translated to Arabic language to fit the spoken language that uses in Libya.

Pilot study: The questionnaire will pilot-tested by convenient sampling. Before conducting the survey, the instrument will be given to a group of people who have used internet banking. In order to refinement of the instrument, the pilot respondents will be interviewed after completion of the questionnaire to get their comments in terms of the questionnaires' length, format, readability, translation and clarity. As observed by Colton and Covert, pre-testing is a valuable part of the design and validation process. The results of the pilot study will be evaluated using Cronbach's reliability and factor analysis. Cronbach's reliability coefficient will first calculate the items of each construct. The standard lower bound for Cronbach's alphas is .70 (Hair, Anderson, Tatham, \& Black, 1998). Items that are not statistically significantly will be eliminated. A factor analysis will be then performed to examine whether the items will produce the expected number of factors. Hair (1998) consider a measure as significant if its factor loading is greater than .50 when the sample size is 120 ; this criterion will be adopted to examine the item loadings of all measures.

Samples and data collection: We will use a survey to collect data. This study will be employed a field survey of internet banking customers to gather data for hypothesis testing and to address research objectives. Based on calculation done by online software assuming $95 \%$ confidence level and 5 for confidence interval, the size of 450 samples will be randomly conducted to represent internet banking customers' population in Libya. Moreover, sample size should be greater than five times and less than ten times the parameters (Bentler \& Chou, 1987), and a sample size of at least 200 is necessary for critical model testing (Hoelter, 1983).In addition, to ensure that the samples are regular users of internet banking, only those who have accessed their accounts online will be eligible. In addition, in order to increase the response rate, random samples will be encouraged to participate voluntary and a kind reminder about the goal of the study will be given. Also, regarding analysis of the data that will be 
collected, we will use SPSS for descriptive statistics, exploratory factor analysis, and reliability analysis, including sample statistics, and AMOS 18, the structural equation modelling program, in the confirmatory factor analysis and covariance structure analysis of each factor..

\section{Conclusion}

We are motivated to answer the research questions in order to enhance the continued use of internet banking. Just because most continued use of internet, banking models such as ECM-IT does not fully show continued use behaviour from relational and cognitive views. In this paper, hence, we proposed an integrated model by extending ECM and adding new construct, which are reputation, recommendation and self-efficacy to cover the cognitive view. In addition, by combining ECM-IT and CTT may add more strength to the model to cover the relational view. The model will be applied to the context of internet banking services. We will conduct the field survey of internet banking service customers. Then, we will empirically test our research hypotheses using data obtained from the survey. Finally, we will suggest theoretical and empirical implications of the findings.

\section{References}

Abukhzam, M. \& Lee, A. (2010). Factors affecting bank staff attitude towards e-banking adoption in Libya. The Electronic Journal on Information Systems in Developing Countries EJISDC, 42(2), 1-15.

Adapa, S. (2011). Continued and frequent use of internet banking by Australian consumers: Identification of the factor components. Journal of Internet Banking and Commerce, 16(2).

Aydin, S. \& Özer, G. (2005). The analysis of antecedents of customer loyalty in the Turkish mobile telecommunication market. European Journal of Marketing, 39, (7/8), 910-925.

Barnes, S. \& Vidgen, R. (2000). Assessing the quality of auction web sites. Proceedings of the Eighth European Conference on Information Systems, 1, 298-305.

Bentler, P. M. \& Chou, C. P. (1987). Practical issues in structural modeling. Sociological Methods \& Research, 16(1), 78-117. doi: 10.1177/0049124187016001004

Bhattacherjee, A. (2001b). Understanding information systems continuous: An expectation- confirmation model. [RESEARCH ARTICLE]. MIS Quarterly, 25(3), 351-370.

Bhattacherjee, A. (2001a). An empirical analysis of the antecedents of electronic commerce service continuance. Elsevier Science B.V. Decision Support Systems, 32(2), 201-214.

Bhattacherjee, A., Perols, J. \& Sanford, C. (2008). information technology continuance: a theoretic extension and empirical test. Journal of Computer Information Systems, 49(1), 17-26.

Bolton, R. N. \& Lemon, K. N. (1999). A dynamic model of customers' usage of services: Usage as an antecedent and consequence of satisfaction. Journal of Marketing Research, 36(2), 171-186.

Casaló, L. V., Flavián, C. \& Guinalíu, M. (2008). The role of satisfaction and website usability in developing customer loyalty and positive word-of-mouth in the e-banking services. International Journal of Bank Marketing, 26(6), 399-417. doi: 10.1108/02652320810902433

CBL annual report. (2007). Retrieved from http://www.cbl.gov.ly/pdf/RTGS.pdf.

Chen, E. T. (2004). Commitment and trust on B2C e-commerce. Paper presented at the IRMA International Conference. http://www.irma-international.org/viewtitle/32383/

Chiou, J. S. (2004). The antecedents of consumers' loyalty toward Internet service providers. Information \& Management, 41(6), 685-695. doi: 10.1016/j.im.2003.08.006

Cho, V., Cheng, T. C. E. \& Hung, H. (2009). Continued usage of technology versus situational factors: An empirical analysis. Journal of Engineering and Technology Management, 26(4), 264-284. doi: 10.1016/j.jengtecman.2009.10.003

Colgate, M. \& Lang, B. (2001). Switching barriers in consumer markets: an investigation of the financial services industry. Journal of consumer marketing, 18(4), 332-347.

Davis, F. D. (1989). Perceived usefulness, perceived ease of use, and user acceptance of information technology. MIS Quarterly, 13(3), 319-340.

East, R., Hammond, K. \& Lomax, W. (2008). Measuring the impact of positive and negative word of mouth on brand purchase probability. International Journal of Research in Marketing, 25(3), 215-224. doi: 10.1016/j.ijresmar.2008.04.001

Eastlick, M. A., Lotz, S. L. \& Warrington, P. (2006). Understanding online B2C relationships: An integrated model of privacy concerns, trust, and commitment. Journal of Business Research, 59(8), 877-886. doi: 10.1016/j.jbusres.2006.02.006

Elmezni, I. \& Gharbi, J. E. (2010). Mediation of cognitive absorption between users' time styles and website satisfaction. Journal of Internet Banking and Commerce, 15(1). 
Eriksson, K. \& Nilsson, D. (2007). Determinants of the continued use of self-service technology: The case of Internet banking. Technovation, 27(4), 159-167. doi: 10.1016/j.technovation.2006.11.001

Ernovianti, E., Kamariah-Nik-Mat, N., Kassim, U., Rashid, R. \& Syaheera-Meor-Shaari, M. (2012). The usage of internet banking service among higher learning students in Malaysia. American Journal of Economics, 2(4), 105-108. doi: 10.5923/j.economics.20120001.24

Gefen, D., Karahanna, E. \& Straub, D. W. (2003). Inexperience and experience with online stores: The importance of TAM and trust. IEEE, 50(3), 307-321

Goode, M. M. H. \& Harris, L. C. (2007). Online behavioural intentions: an empirical investigation of antecedents and moderators. European Journal of Marketing, 41(5/6), 512-536. doi: $10.1108 / 03090560710737589$

Hair, J. F., Anderson, R. E., Tatham, R. L. \& Black, W. C. (1998). Multivariate data analysis. 5th ed. New Jersey: Prentice Hall.

Hashim, A. A. \& Chaker, M. N. (2008). Customers' perception of online banking in Qatar. Journal for Global Business Advancement, 2(3), 252-263. doi: 10.1504/JGBA.2009.028704

Ho, S. H., \& Ko, Y. Y. (2008). Effects of self-service technology on customer value and customer readiness: The case of Internet banking. Internet Research, 18(4), 427-446. doi: $10.1108 / 10662240810897826$

Hoelter, J. W. (1983). The analysis of covariance structures: Goodness-of-fit indices. . Sociological Methods and Research, 11(9), 325-344.

Jarvenpaa, S. L., Tractinsky, N. \& Vitale, M. (2000). Consumer trust in an Internet store. Journal Information Technology and Management, 1, 45-71.

Jones, T. O. \& Earl Sasser, J. (1995). Why satisfied customers defect. Harvard Business Review, 71, 88-99.

Karjaluoto, H., Mattila, M. \& Pento, T. (2002). Factors underlying attitude formation towards online banking in Finland. International Journal of Bank Marketing, 20(6), 261-272. doi: $10.1108 / 02652320210446724$

Kim, J., Jin, B. \& Swinney, J. L. (2009). The role of etail quality, e-satisfaction and e-trust in online loyalty development process. Journal of Retailing and Consumer Services, 16(4), 239-247. doi: 10.1016/j.jretconser.2008.11.019

Kim, Y. \& Crowston, K. (2011). Technology adoption and use theory review for studying scientists' continued use of cyber-infrastructure. Journal of the American Society for Information Science and Technology, 48(1), 1-10. doi: DOI: 10.1002/meet.2011.14504801197

Konuk, F. A. \& Konuk, F. (2013). The relationship between service quality, economic and switching costs in retail banking. Business Systems Review, 2(1). doi: 10.7350/bsr.b01.2013

LCBD annual report. (2009). The 13th LBCD Annual Report. Retrieved from Libyan Bank of Commerce \& Development website http://www.bcd.ly/arabic/default.aspx.

Lee, Y. \& Kwon, O. (2009). Can affective factors contribute to explain continuance intention of web-based services? ACM, 978-1-60558-586-4/09/08...\$10.00.

Li, D. \& Chau, P. Y. K. (2009). Acceptance of internet-based services: A comparison of three models. Pacific Asia Journal of the Association for Information Systems, 1(3), 1-24.

Maroofi, F. \& Nazaripour, M. (2012). Factors affecting customer loyalty of using internet banking in Iran. International Journal of Academic Research in Accounting, Finance and Management Sciences, 2(4), 53-65.

Mikkelsen, M. R. (2002). Viewers talking about television advertising: Introducing verbal referral as a supplementary measure of advertising effectiveness: Marketing--University of Auckland.

Min, Q. \& Shenghua, X. (2007). An extended expectation confirmation model for information systems continuance. IEEE, 1-4244-1312-5/07/\$25.00.

Mukherjee, A. \& Nath, P. (2007). Role of electronic trust in online retailing: A re-examination of the commitment-trust theory. European Journal of Marketing, 41(9/10), 1173-1202. doi: 10.1108/03090560710773390

Nasrin-Danesh, S., Ahmadi-Nasab, S. \& Choon-Ling, K. (2012). The study of customer satisfaction, customer trust and switching barriers on customer retention in Malaysia hypermarkets. International Journal of Business and Management, 7(7), 141-150. doi: 10.5539/ijbm.v7n7p141

Nor, K. M. \& Pearson, J. M. (2007). The influence of trust on internet banking acceptance. Journal of Internet Banking and Commerce, 12(2).

Oliver, R. L. \& Linda, G. (1981). Effect of satisfaction and its antecedents on consumer preference and intention. Advances in consumer research, 8(1), 88-93.

Pikkarainen, T., Pikkarainen, K., Karjaluoto, H. \& Pahnila, S. (2004). Consumer acceptance of online banking: An extension of the technology acceptance model. Emerald Group Publishing Limited, 14(3), 224-235. doi: 10.1108/10662240410542652 
Riquelme, H. E., Mekkaoui, K. A. \& Rios, R. E. (2009). Internet banking customer satisfaction and online service attributes. Journal of Internet Banking and Commerce JIBC, 14(2).

Rogerson, W. P. (1983). Reputation and product quality. The Bell Journal of Economics, 14(2), 508-516.

Ryssel, R., Ritter, T. \& Gemünden, H. G. (2004). The impact of information technology deployment on trust, commitment and value creation in business relationships. Journal of Business \& Industrial Marketing, 19(3), 197-207. doi: 10.1108/08858620410531333

Schlich, B. (2012). Global Consumer Banking Survey 2012, Retrieved from Ernst \& Young Institute websitehttp://www.ey.com/Publication/vwLUAssets/Global_Consumer_Banking_Survey_2012_ The_customer_takes_control/\$FILE/Global_Consumer_Banking_Survey_2012.pdf.

Seyed-Ghorban, Z. \& Tahernejad, H. (2012). A study on effect of brand credibility on word of mouth: With reference to internet service providers in Malaysia. International Journal of Marketing Studies, 4(1), 26-37. doi: 10.5539/ijms

Sheng, M. \& Lu, X. X. (2009). An empirical study on influencing factors of customer satisfaction to individual internet banking. IEEE, 978-1-4244-5273-6/09/\$26.00.

Singh, H. (2006). The importance of customer satisfaction in relation to customer loyalty and retention. UCTI Working Paper. Asia Pacific University College of Technology \& Innovation. Retrieved from http://www.ucti.edu.my/wps/issue1/wp-06-06-paper.pdf.

Thong, J. Y. L., Hong, S. J. \& Tam, K. Y. (2006). The effects of post-adoption beliefs on the expectationconfirmation model for information technology continuance. International Journal of HumanComputer Studies, 64(9), 799-810. doi: 10.1016/j.ijhcs.2006.05.001

Twati, J. M. (2008). The Influence of Societal Culture on the Adoption of Information Systems: The Case of Libya. Communications of the IIMA, 8(1), 1-12.

Vatanasombut, B., Igbaria, M., Stylianou, A. C. \& Rodgers, W. (2008). Information systems continuance intention of web-based applications customers: The case of online banking. Information \& Management, 45(7), 419-428. doi: 10.1016/j.im.2008.03.005

Wang, Y. S., Wang, Y. M., Lin, H. H. \& Tang, T. I. (2003). Determinants of user acceptance of Internet banking: an empirical study. International Journal of Service Industry Management, 14(5), 501519. doi: 10.1108/09564230310500192

Wenchao, W. \& Jordan, D. (2009). The determinants of the adoption of internet banking by Chinese consumers. IEEE, 978-1-4244-3541-8/09/\$25.00, 760- 763.

Wentzel, J. P., Wentzel, J. M., Sundar, D. K. \& SarmaYadavalli, V. (2011). Drivers of e-commerce/ebussiness success: constructs, antecedents and moderators in adoption of technology enabled products and services. Paper presented at the The 41st International Conference on Computers \& Industrial Engineering, Los Angeles, CA USA, 924-929.

Yang, Z. \& Peterson, R. T. (2004). Customer perceived value, satisfaction, and loyalty: the role of switching costs. Psychology \& Marketing, 21(10), 799-822.

Yee, B. \& Faziharudean, T. M. (2010). Factors affecting customer loyalty of using internet banking in Malaysia. Journal of Electronic Banking Systems, 2010, 1-22. doi: 10.5171/2010.592297

Yoon, H. S. \& Barker Steege, L. M. (2012). Development of a quantitative model of the impact of customers' personality and perceptions on Internet banking use. Computers in Human Behavior, 07475632/\$. doi: 10.1016/j.chb.2012.10.005

Zahid, N., Mujtaba, A. \& Riaz, A. (2010). Consumer acceptance of online banking. European Journal of Economics, Finance and Administrative Sciences,( Issue 27), 44-52. 